\title{
The Augmented SOLOW Model And The OECD Sample
}

Giorgio Canarella (gcanare@ calstatela.edu), California State University, Los Angeles Stephen K. Pollard (spollar2@calstatela.edu), California State University, Los Angeles

\begin{abstract}
In their influential work on the augmented Solow model, Mankiw, Romer and Weil (1992) showed that cross-section evidence was reasonably consistent with the Solow growth model augmented to include human capital for a wide range of countries. However, for the sample of OECD countries, they found that the model had low explanatory power and underestimated the output elasticity of physical capital. We revisit their seminal work using data from the recently released version 6.1 of the Penn World Table. We find that the ability of the augmented Solow model to explain the cross-country variation in income per capita in the OECD sample improves significantly. Our results highlight the importance of taking into account changes that take place over time in the collection and measurement of national accounts data in estimating and testing the augmented Solow model.
\end{abstract}

\subsection{Introduction}

In one of the most influential works in growth economics in the last decade, Mankiw, Romer and Weil (1992) showed that cross-country evidence was reasonably consistent with the Solow growth model augmented to include human capital. Their model accounted for almost 80 per cent of the cross-country variation in income per capita and correctly estimated the output elasticity of both physical and human capital in two of their three samples. ${ }^{1}$

However, for the third sample, the group of 22 OECD countries, they found that the augmented Solow model in its steady-state specification had low explanatory power (roughly one-third of the other two samples), produced less precise estimates of the coefficients on investment in physical capital and population growth and yielded a measure of the output elasticity of physical capital that was less than one-half the value obtained in each of the other two samples. These discrepancies were lessened in the estimated out-of-steady-state specification, as the explanatory power of the augmented Solow model for the OECD sample increased to a level that was consistent with the other two samples, the relative precision of the estimates of coefficients on population growth and investment in physical capital increased and the output elasticity of physical capital was no longer at variance with its generally accepted empirical value of one-third. Mankiw, Romer and Weil (1992, p.428) reconciled the "similarity across samples" of the out-of-steady-state results with the "dissimilarity across samples" of the results obtained in the steady-state specifications by putting forth the conjecture that "departures from steady state represent a larger share of cross-country variation in income per capita for the OECD than for the broader samples."

Nonneman and Vanhoudt (1996) used an omitted variable argument to explain the poor performance of the OECD sample. They showed that by further extending the augmented Solow model to include a third type of capital, technological know-how, the steady-state specification of the model could explain about 75 per cent of the crosscountry variation in the level of income per capita in the OECD countries. Nonneman and Vanhoudt's extension did not completely reverse the findings of Mankiw, Romer and Weil (1992), as investment in both physical and human capital had no statistically significant impact on the level of income per capita in 1985 . Further, their implied

Readers with comments or questions are encouraged to contact the authors via email. 
estimates (not reported in their Table III, p.948) of the output elasticities of physical and human capital remained implausibly low.

In this paper, we present an alternative explanation for the apparent inability of the augmented Solow model to adequately account for the cross-country variation of income per capita in the OECD sample. We argue that the results of Mankiw, Romer, and Weil (1992) and Nonneman and Vanhoudt (1996) are largely dependent on the national accounts data available at the time their analyses were undertaken rather than the outcome of a misspecification of the model or the presence of extreme departures from steady state. ${ }^{2}$ We evaluate this alternative explanation by means of the 6.1 version of the Penn World Table that was released in October 2002 (Heston, Summers and Bettina, 2002). The Penn World Table 6.1 takes into account quality improvements in the national accounts data which were not available in earlier versions, such as national accounts revisions, updates to reflect 1996 benchmarks, and changes in base year prices. ${ }^{3}$ The Penn World Table 6.1 represents the $6^{\text {th }}$ version of the work begun by Summers, Kravis and Heston (1980) based on the benchmarks of the United Nations International Comparison Program. ${ }^{4}$

Key to each version, and in particular a major difference between the Penn World Table 4.0 and the Penn World Table 5.0, is the increased usage of new benchmarks (made available through the collection of price data for 1985) in constructing the set of national accounts and less reliance on estimates. The revisions incorporated in the Penn World Table 5.0 led to substantial improvements in the quality of national accounts data, but have not made a lot of difference in the coefficient estimates of the augmented Solow model for the OECD sample. The results of Nonneman and Vanhoudt (1996), who utilized the Penn World Table 5.0, in fact, did not differ significantly from Mankiw, Romer and Weil's findings. Andres, Domenech and Molinas (1996) reached similar conclusions as they compared the estimates of convergence obtained using different versions of the Penn World Table with those derived from national accounts data collected by the OECD.

From a quantitative viewpoint, the main differences between the three versions of the Penn World Table can be seen by comparing the mean and the standard deviation of income per capita in 1985 and the average share of output devoted to physical capital investment between 1960 and 1985 (I/GDP) for the OECD sample. In general, the mean and the standard deviation of income per capita in 1985 for the OECD sample have increased with the release of a newer version of the Penn World Table, which mainly reflected the increase in benchmark values based on newer price series. For example, the mean of income per capita in 1985, as defined by Mankiw, Romer and Weil (1992), increased from $\$ 13,131$ (standard deviation of \$4012) using the Penn World Table 4.0 to $\$ 24,469$ (standard deviation of \$6442) using the Penn World Table 6.1. On the other hand, the mean of the average share of physical capital investment in GDP between 1960 and 1985 decreased from $25.8 \%$ (standard deviation of 5.0\%) using the Penn World Table 4.0 to $24.0 \%$ (standard deviation of 5.1\%) using the Penn World Table 6.1. The revisions in the Penn World Table 6.1 did not substantially distort the relative structure of income per capita. The correlation coefficient between income per capita in 1985 based on the Penn World Table 4.0 and income per capita in 1985 based on the Penn World Table 6.1 is 0.96.

Similarly, the correlation coefficient between income per capita in 1985 based on the Penn World Table 5.0 and income per capita in 1985 based on Penn World Table 6.1 is 0.98, while the correlation coefficient between income per capita in 1985 based on the Penn World Table 4.0 and income per capita in 1985 based on Penn World Table 5.0 is 0.93 . This, however, does not hold true for the average share of output devoted to physical capital investment between 1960 and 1985. The correlation coefficient between I/GDP from the Penn World Table 4.0 and I/GDP from the Penn World Table 5.0 is 0.88 and decreases rapidly as a result of data revisions. The correlation coefficient is 0.79 between I/GDP from the Penn World Table 5.0 and I/GDP from the Penn World Table 6.1, and 0.66 between I/GDP from the Penn World Table 4.0 and I/GDP from the Penn World Table 6.1.

These considerations suggest the need to revisit the issue of the poor performance of the augmented Solow model for the OECD sample using the Penn World Table 6.1. In this paper, we accomplish this in two steps. First, we re-estimate the augmented Solow model using data for the period 1960-1985 from the Penn World Table 6.1, and examine whether the movement towards an optimal set of real national accounts makes a difference in the estimated results for the OECD sample. Second, using the Penn World Table 6.1 in conjunction with an updated set of secondary school enrollment data, we update the estimates of the augmented Solow model assuming that the level 
of per capita income in the year 2000 is the steady-state level. As a by-product of this estimation, we ascertain the plausibility of Mankiw, Romer and Weil's conjecture. That is, given the passage of an additional 15 years, have the OECD countries moved closer to their steady state?

The rest of the paper is organized as follows. The next section puts forth the augmented Solow model and outlines the general specifications retained in the empirical analysis. Section 3 describes in detail the data with a particular emphasis on their sources. The empirical results are presented in Section 4, which also contains a detailed analysis of any significant difference between our results and those obtained by Mankiw, Romer and Weil (1992) and Nonneman and Vanhoudt (1996). The main conclusions and directions for future research are contained in the final section.

\subsection{The Augmented Solow Model}

Mankiw, Romer and Weil (1992) estimated two specifications of the augmented Solow model. The first specification assumes that the economy is in steady state and described by a Cobb-Douglas constant returns to scale production function:

$\left.Y(t)=K(t)^{\alpha} H(t)^{\beta}(A(t)) L(t)\right)^{1-\alpha-\beta}$,

where $Y$ is output, $A$ is technology, $K$ is physical capital, $H$ is human capital, and $L$ is labor.

The parameters $\alpha$ and $\beta$ are the output elasticities with respect to physical and human capital (shares of physical and human capital in total income), respectively. Mankiw, Romer and Weil (1992) extended the Solow dynamics of physical capital accumulation to human capital. Thus the dynamics of growth takes the form:

$\dot{K}(t)=s_{k} Y(t)-\delta K(t)$

$\dot{L}(t)=n L(t)$

$\dot{A}(t)=g A(t)$

$\dot{H}(t)=s_{h} Y(t)-\delta H(t)$,

Where $s_{k}$ and $s_{h}$ denote the fraction of output devoted, respectively, to physical and human capital accumulation, $n$ is the rate of growth of labor, $g$ is technological progress, and $\delta$ is the rate of depreciation. A dot over a variable indicates the derivative with respect to time. Assuming the existence of a steady state with $\alpha+\beta<1$, Mankiw, Romer and Weil (1992) obtained the following steady-state estimable version of the model:

$\ln \left[\frac{Y(t)}{L(t)}\right]=\ln (A(0))+g t-\frac{\alpha+\beta}{1-\alpha-\beta} \ln (n+g+\delta)+\frac{\alpha}{1-\alpha-\beta} \ln \left(s_{k}\right)+\frac{\beta}{1-\alpha-\beta} \ln \left(s_{h}\right)$.

Equation (6) provides the basic framework for testing the augmented Solow model. The model predicts that the steady-state level of income per capita is positively affected by investment in both physical and human capital and negatively affected by population growth, depreciation, and exogenous technological progress, and requires that their coefficients sum to zero. For $\beta \square \square \square \square$ equation (6) reduces to the "textbook" Solow model.

The second specification of the augmented Solow model relaxes the assumption that the economy is in steady state. Letting $y^{*}$ be the steady-state level of income per effective worker and $y(t)$ the actual value at time $t$, Mankiw, Romer and Weil (1992) showed that the speed of convergence $\lambda$ can be obtained by linear approximation around the steady state:

$\frac{d \ln (y(t))}{d t}=\lambda\left[\ln \left(y^{*}\right)-\ln (y(t))\right]$, 
where

$\lambda=(n+g+\delta)(1-\alpha-\beta)$

The first-order differential equation in (7) implies that

$\ln (y(t))=\left(1-\mathrm{e}^{-\lambda t}\right) \ln \left(y^{*}\right)+\mathrm{e}^{-\lambda t} \ln (y(0))$

where $y(0)$ is income per effective worker at some initial point in time. Finally, substituting for $y^{*}$ and subtracting $\ln (y(0))$ from both sides yields:

$$
\begin{array}{r}
\ln (y(t))-\ln (y(0))=-\left(1-\mathrm{e}^{-\lambda t}\right) \frac{\alpha+\beta}{1-\alpha-\beta} \ln (n+g+\delta)+\left(1-\mathrm{e}^{-\lambda t}\right) \frac{\alpha}{1-\alpha-\beta} \ln \left(s_{k}\right) \\
+\left(1-\mathrm{e}^{-\lambda t}\right) \frac{\beta}{1-\alpha-\beta} \ln \left(s_{h}\right)-\left(1-\mathrm{e}^{-\lambda t}\right) \ln (y(0))
\end{array}
$$

Since income per effective worker $y(t)$ is not observable, Mankiw, Romer and Weil (1992) expressed equation (9) in terms of income per capita and obtained the out-of-steady-state estimable version of the model:

$$
\begin{aligned}
\ln \left[\frac{Y(t)}{L(t)}\right]-\ln \left[\frac{Y(0)}{L(0)}\right]= & \left(1-\mathrm{e}^{-\lambda t}\right) \ln (A(0))+g t-\left(1-\mathrm{e}^{-\lambda t}\right) \frac{\alpha+\beta}{1-\alpha-\beta} \ln (n+g+\delta) \\
& +\left(1-\mathrm{e}^{-\lambda t}\right) \frac{\alpha}{1-\alpha-\beta} \ln \left(s_{k}\right)+\frac{\beta}{1-\alpha-\beta} \ln \left(s_{h}\right)-\left(1-\mathrm{e}^{-\lambda t}\right) \ln \left[\frac{Y(0)}{L(0)}\right] .
\end{aligned}
$$

Solow growth model predicts conditional convergence, i.e. convergence to a steady state that may differ across countries. Thus, the finding that the parameter estimate of $\ln \left[\frac{Y(0)}{L(0)}\right]$ is significantly less than zero, which implies $\lambda>0$, provides additional evidence in favor of the augmented Solow model.

\subsection{Data}

All the variables were constructed following as close as possible the methodology and the definitions employed by Mankiw, Romer and Weil (1992). $Y / L$ for a given country was measured by real GDP per person of working age (defined as the age cohort 15 to 64 years). This variable was obtained by multiplying $Y / P$, real GDP per capita adjusted for terms of trade changes for a given country, in 1996 international prices (source: variable rgdptt, Penn World Table 6.1), by $L / P$, where $P$ is total population (source: variable $P O P$, Penn World Table 6.1) and L is working population, age 15 to 64 years (source: World Bank Development Indicators Online (December 2002). The variable $s_{k}$ for a given country was measured by I/GDP, the average share of GDP devoted to investment in physical capital between 1960 and 1985 or between 1960 and 2000 (source: variable ki, Penn World Table 6.1). The variable $s_{h}$ for a given country was measured by SCHOOL, the average fraction of working age population in secondary school (age 15 to 19 years) between 1960 and 1985 (source: Mankiw, Romer and Weil (1992)) or between 1960 and 2000. SCHOOL between 1960 and 2000 was obtained by updating this measure for 1990, 1995 and 2000 following the identical procedure utilized by Mankiw, Romer and Weil (1992). We first obtained data on gross enrollment for secondary education (the ratio, expressed as a percentage, of the number of students enrolled in secondary school to the population in the age cohort 12 to17 years) (source: World Bank Edstats (December 2002). We then multiplied this value by the population in the age cohort 15 years to19 years, the closest age cohort available (again following Mankiw, Romer and Weil (1992)) (source: United States Census Bureau, Population Division, International Programs Center, International Database (October 2002) and divided it by $L$, the working population, ages 15 to 64 years (source: World Bank Development Indicators Online (December 2002). The SCHOOL variable for the period 1960-2000 was then obtained by multiplying its 1960-1985 value (source: Mankiw, Romer and Weil (1992)) by 6 
(the number of panel values, at 5 year intervals, for the period 1960-1985), adding this value to the ones obtained for 1990, 1995 and 2000 and then dividing this sum by 9 . The resulting value is the average fraction of the working age population enrolled in secondary school between 1960 and 2000. The variable $n$ for a given country refers to the average annual rate of growth of the working age population (ages 15 to 64years) between 1960 and 1985 (source: World Bank Development Indicators Online (December2002), or between 1960 and 2000 (source: World Bank Development Indicators Online (December 2002). The rate of depreciation $\delta$ and the rate of technological progress $\mathrm{g}$ are assumed, as in Mankiw, Romer and Weil (1992), constant with their sum equal to 0.05 .

\subsection{Empirical Results}

The results of our empirical analysis set forth three main interrelated points. First, the results point out that the cross-country variation in income per capita in the OECD sample is better explained, and the impact of investment in both human and physical capital is more fully accounted for, when the augmented Solow model is estimated using data from the Penn World Table 6.1. Second, the results also lend some empirical support to Mankiw, Romer and Weil's conjecture that in 1985 the OECD countries were farther from their steady state than the rest of the world. At the same time, our results show that in 1985 countries in the OECD sample were closer to their steady state than thought to be by Mankiw, Romer and Weil (1992). Third, the results also indicate that when the analysis is extended to the year 2000, the gap from the steady-state level of income per capita in the OECD sample is reduced. This reduction, in turn, is accompanied by an increase in the explanatory power of the steady-state augmented Solow model (and, correspondingly, a decrease in the explanatory power of its out-of-steady-state specification), along with a realignment of the steady-state estimates of the structural parameters $\alpha$ and $\beta$ with their corresponding out-of-steady-state estimates.

We now turn our attention to how these results were attained and the specific findings of our regression estimates. ${ }^{5}$ The results of the least-squares (OLS) estimation ${ }^{6}$ of the "textbook" and augmented Solow models in their steady-state specifications are presented in Tables 1 and 2, for the years 1985 and 2000, respectively. The explanatory power of "textbook" Solow model improves considerably when data from the Penn World Table 6.1 are used, and can now explain approximately 20 per cent of the cross-country variation in income per capita in the OECD sample. Mankiw, Romer and Weil (1992) as well as Nonneman and Vanhoudt (1996), on the other hand, could only explain approximately 6 per cent of the cross-country variation in income per capita. The coefficient estimates have the predicted sign - the level of output per capita is positively related to the share of output devoted to physical investment and negatively related to the rate of population growth. However, only the share of output devoted to physical investment has a statistically significant impact on the level of income per capita. The linear restriction implied by the model (i.e., the coefficients of $\ln (\mathrm{I} / \mathrm{GDP})$ and $\ln (n+0.05)$ are equal in magnitude and opposite in sign) cannot be rejected at any conventional level and the residuals present no evidence of nonnormality. There is, however, some evidence of heteroskedasticity, especially in the regression for the year 2000. Most importantly, the value of $\alpha$ implied by the coefficient estimates of the constrained regression no longer contradicts the prediction that $\alpha=1 / 3$.

The performance of the augmented Solow model also improves substantially when data based on the Penn World Table 6.1 are used. The coefficient estimates have the predicted sign - the level of output per capita is positively related to the shares of output devoted to physical and human capital investment and negatively related to the rate of population growth. Investment in both human and physical capital has a statistically significant impact on the level of income per capita in both in 1985 and 2000. Similarly, the restricted estimates for both 1985 and 2000 have the predicted signs and are statistically significant. These findings, too, differ from Mankiw, Romer and Weil's and Nonneman and Vanhoudt's. The linear restriction implied by the augmented Solow model (i.e., the sum of the coefficients of $\ln (\mathrm{SCHOOL}), \ln (\mathrm{I} / \mathrm{GDP})$ and $\ln (n+0.05)$ equals zero) is also not rejected, and the analysis of the residuals indicates that there is no evidence of non-normality or heteroskedasticity for any of the estimated equations. The addition of the measure of human capital investment increases the adjusted $R^{2}$ even further. The augmented Solow model can now explain approximately 40 per cent of the cross-country variation in the level of income per capita in the OECD sample. The adjusted $R^{2}$ of the unrestricted regression is approximately $58 \%$ higher than that reported by Mankiw, Romer and Weil (1992) and 73\% higher than Nonneman and Vanhoudt (1996). These 
findings noticeably reveal that using data from earlier versions of the Penn World Table had the effect of overestimating the extent of the departure of the countries in the OECD sample from their steady state.

The increased relative precision of the parameter estimates leads to increased relative precision of the estimates of the structural parameters $\alpha$ and $\beta$. The implied magnitudes of $\alpha, 0.20$, is greater than the one reported by Mankiw, Romer and Weil (1992), 0.14, and, most importantly, is no longer insignificant, while the magnitude of $\beta, 0.28$, is less than the value reported by Mankiw, Romer and Weil (1992), but remains highly significant. This implies that $\alpha+\beta$, the output elasticity of total capital, and $1-\alpha-\beta$, the output elasticity of effective labor, are 0.49 and 0.51 , respectively, with a standard error of 0.07 . These estimates are close to those obtained by Mankiw, Romer and Weil (1992) (0.51 and 0.47, respectively), but have a higher degree of precision, given the magnitude of the standard error. The other difference concerns the relative percentage weights of physical and human capital in the output elasticity of total capital. Our results indicate that physical and human capital account for 41 per cent and 59 per cent, respectively, of the output elasticity of total capital, compared to 27 per cent and 73 per cent in Mankiw, Romer and Weil (1992). These results are further accentuated by the estimates for the year 2000 and provide evidence that this extension of the regression analysis not only improves the relative precision of the parameter estimates, but also enhances impact of the rate of population growth and the accumulation of physical and human capital on the income per capita in the OECD sample. The implied estimates of $\alpha$ and $\beta$ are 0.18 and 0.36 , respectively, and are highly significant. This means that $\alpha+\beta$, the output elasticity of total capital, and $1-\alpha-\beta$, the output elasticity of effective labor, are 0.54 and 0.46 , respectively, with a standard error of 0.05 . These values are consistent with those obtained by Mankiw, Romer and Weil (1992), but have a higher relative precision. The relative percentage weights of physical and human capital in the output elasticity of total capital also change, with physical capital accounting less (33 per cent) and human capital accounting more (64 per cent) compared to 1985.

The results for the year 2000 also show a further increase in the explanatory power of the augmented Solow model. The adjusted $R^{2}$ in the restricted regression is 0.44 , which represents an increase of approximately 20 per cent over the corresponding value in the restricted regression for 1985 . We interpret this finding as providing evidence in favor of the conjecture put forward by Mankiw, Romer and Weil (1992): the countries in the OECD sample are farther away from their steady-state levels of income per capita than the rest of the world, but, tendentially, over time, are moving closer to those levels. It is also worth noting that in the unrestricted regressions the adjusted $R^{2}$ of the "textbook" Solow model decreases from 0.20 in 1985 to 0.15 in 2000, whereas, at the same time, the adjusted $R^{2}$ of the augmented Solow model increases from 0.38 in 1985 to 0.42 in 2000. Since human capital is an omitted variable in the "textbook" Solow model, this result points to the increased role of human capital in explaining the cross-country variation in the level of income per capita as the economies in the OECD sample move closer to their steady-state levels.

The augmented Solow model predicts that that the steady-state marginal product of physical capital, net of depreciation, varies positively with the rate of growth of population and negatively with the saving rate. It can be shown that the steady-state specification of the model implies that the net marginal product of physical capital can be obtained as follows:

$M P K-\delta=\alpha(n+g+\delta) / s_{k}-\delta$

Assuming $g=0.02$ and $\delta=0.03$, and using the implied estimates of $\alpha$ and $\beta$ from Tables 1 and 2 , we found that for 2000 the mean of the steady-state net marginal product of physical capital is 1.8 per cent, and the standard deviation is 1.4 per cent; similarly, for 1985 , the mean is 2.4 per cent and the standard deviation is 2.0 per cent. These values are higher than the ones that can be obtained using the estimates of Mankiw, Romer and Weil (1992), but lower than those obtained by Nonneman and Vanhoudt (1996). ${ }^{7}$ For the United States, using equation (11), we find that the net marginal product of capital is 4.6 per cent for 1985 and 3.3 for 2000. These values are more consistent with the average real interest rates and the observed interest rate differentials for the United States. The augmented Solow model also predicts that the net marginal product of physical capital is low in countries where the share of output devoted to investment in physical capital is high. Among the countries in the OECD sample, Turkey has the lowest share of output devoted to physical capital and Norway has the highest. Again, using equation (11), we find that the net marginal product of physical capital for Turkey is 9.6 per cent and for Norway is 0.4 per cent for 1985; similarly, 
for 2000, Turkey has a net marginal product of 6.5 per cent and Norway has a net marginal product of capital of 0.3 per cent. ${ }^{8}$

Lastly, we examined the relationship between the explanatory powers of equation (6) and equation (10). Equation (10) relaxes the assumption that the observed levels of income per capita correspond to their steady-state values and makes two predictions: first, countries with a higher initial level of income per capita experience slower growth, and, second, for a given level of initial income per capita, countries with higher investment shares in physical and human capital and lower population growth experience faster growth. The results of the least-squares (OLS) estimation of the augmented Solow model, as well as the "textbook" Solow model in their out-of-steady-state specification are presented in Tables 3 and 4, for the periods 1960-1985 and 1960-2000, respectively. For reasons of comparability with Mankiw, Romer and Weil (1992), tests for unconditional (absolute) convergence are also reported in these Tables.

The results indicate that there is a significant tendency toward convergence, both conditionally and unconditionally, in the OECD sample, as was reported by Mankiw, Romer and Weil (1992). In each of the unconditional convergence regressions, the coefficient estimate on $\ln (Y / L(1960))$ has the predicted sign - a higher level of output per capita in 1960 is correlated with slower growth over the sample periods 1960-1985 and 1960$2000-$ and is highly significant. The implied magnitude of $\lambda$ does not reveal any significant difference from Mankiw, Romer and Weil (1992), but the residuals, particularly in the regression for the period 1960-2000, present evidence of heteroskedasticity and non-normality. The addition of physical capital investment and population growth rate improves substantially the explanatory power of the regression and decreases the estimated coefficient on $\ln (Y / L(1960))$, as in Mankiw, Romer and Weil (1992), and eliminates the problems of heteroskedasticity and nonnormality in the residuals. Similarly to what Mankiw, Romer and Weil (1992) reported, the inclusion of human capital investment further increases the adjusted $R^{2}$ and further reduces the estimated coefficient on $\ln (Y / L(1960))$. The coefficient estimate of $\ln (Y / L(1960))$ also further decreases in the period 1960-2000, and the decrease is large enough to maintain the implied $\lambda$, the average speed of convergence, at approximately 2 per cent per year, which is not much different from that obtained by Mankiw, Romer and Weil (1992). With a value of $\lambda$ of approximately 2 per cent, the half-life of convergence for the countries in the OECD sample is about 33 years. Mankiw, Romer and Weil (1992) argued that World War II has caused extensive departures from steady state and has affected the countries in the OECD sample more than the rest of the world. Thus, this value of $\lambda$ implies that 70 per cent of the departure from steady state which originated as a result of World War II has largely disappeared by the end of the year 2000.

The coefficient estimates of the rate of population growth and physical and human capital accumulation have the predicted sign and their significance increases when the regression is extended to the year 2000 . On the other hand, the adjusted $R^{2}$ decreases, although not to a large extent. This result, while seemingly counter-intuitive, indicates that as the countries in the OECD sample move closer to their steady-state level of income per capita, the explanatory power of the steady-state specification of the augmented Solow model increases, but the explanatory power of the out-of-steady-state dynamics lessens. In both cases, however, the parameters are more precisely estimated.

Although the "textbook" Solow model performs better using the Penn World Table 6.1, its out-of-steadystate estimates imply a value of $\alpha$ that is implausibly high and significantly departs from its predicted value of $1 / 3$. The augmented Solow model, instead, yields values of $\alpha$ and $\beta$ for the period 1960-1985 that are nearly identical to Mankiw, Romer and Weil's findings and are more in conformity with their generally accepted empirical values. However, the extension of the sample period to the year 2000 reverses some of the out-of-steady-state findings of Mankiw, Romer and Weil (1992). In particular, for the sample period 1960-2000, the implied $\alpha, 0.27$, is lower and the implied $\beta, 0.35$, is much higher than their estimates of 0.38 and 0.23 , respectively. It is also interesting to note that the out-of-steady state estimates, especially $\beta$, appear to converge to their corresponding steady-state estimates as the analysis is extended to the year 2000.

In Mankiw, Romer and Weil (1992) the implied steady-state estimates of the structural parameters $\alpha$ and $\beta$ diverge remarkably from their corresponding out-of-steady-state estimates. The output elasticity of physical capital 
is 0.14 in the steady state specification and 0.38 in the out-of-steady-state specification. Similarly, the output elasticity of human capital is 0.37 in the steady-state version, and 0.23 in the out-of-steady-state version. In addition, their out-of-steady-state estimates are significantly different from zero, while their steady-state estimates are not. The most interesting result of our analysis is the invariance of the estimate of the output elasticity of human capital across specifications, as well as its increased precision, over the period 1960-2000. One possible explanation is that the impact of human capital is being more fully realized over this forty-year period, with the result that our estimate of $\beta$ more adequately measures the impact of human capital on output per capita. Temple (2000) showed that if $s_{h}$ increases by a factor $\theta$, output per capita ultimately increases by a factor equal to $\theta^{\frac{\beta}{1-\alpha-\beta}}$. Temple calculated, using Mankiw, Romer and Weil (1992, p. 429) estimates of $\alpha$ and $\beta(0.38$ and 0.23$)$ that if $s_{h}$ increases by 10 percent $(\theta=$ 1.1 , output per capita would increase by 6 per cent. Repeating these calculations using the implied $\alpha$ and $\beta$ in Tables 3 and 4 yields, for a 10 per cent increase in $s_{h}$, an increase in output per capita of 5 per cent for the period 19601985, which is not much dissimilar from Mankiw, Romer and Weil (1992). However, when the implied estimates of $\alpha$ and $\beta$ obtained for the period 1960-2000 are used, output per capita increases by 9 per cent, for a 10 percent increase in $s_{h}$.

\subsection{Conclusions and Future Directions}

In their much cited and influential paper, Mankiw, Romer and Weil (1992) found that the augmented Solow model did not perform as well for the OECD sample as it did for their other two samples. In this paper, we revisited this issue using data from the most recent version of the Penn World Table. We found that improvements of national accounts data contained in the Penn World Table 6.1 make a remarkable difference in the statistical performance of the augmented Solow model for the OECD sample, both in terms of explanatory power and relative precision of the coefficient estimates. These results clearly suggest that, as is always the case in empirical research, the quality of data matters immensely and highlight the importance of taking into account changes that take place over time in the collection and measurement of national accounts data in estimating and testing the augmented Solow model. These results also indicate that the large body of research on human capital and economic growth need to be re-examined in light of the availability of new data sources.

The findings also lend some empirical support to Mankiw, Romer and Weil's conjecture that in 1985 the OECD countries were farther from their steady state than the rest of the world. At the same time, they indicate that by 2000 these departures are reduced, resulting in estimates of the structural parameters, especially the output elasticity of human capital, that are invariant to the two alternative specifications of the augmented Solow model. Finally, the analysis reveals the increasing importance of investment in human capital to the countries in the OECD sample as measured by the responsiveness of output to such investment. This finding re-enforces the conclusions of a recently released OECD (2003) policy study on adult learning in nine of the countries in the OECD sample, which re-emphasizes the need of continuous investment in human capital to further economic growth and social development given that these economies are becoming more and more knowledge-based economies.

\section{References}

1 Andres, Javier, Domenech, Rafael, and Cesar Molinas (1996), "Macroeconomic Performance and Convergence in OECD Countries," European Economic Review, 40, 1683-1704.

2 Heston, Alan, Summers, Robert, and Bettina Aten, Penn World Table Version 6.1, (Center for International Comparisons at the University of Pennsylvania (CICUP), October 2002), http://pwt.econ.upenn.edu (Mark 5.6 and Penn World Table 6.1).

3 Islam, Nazrul (1995), "Growth Empirics: A Panel Data Approach," Quarterly Journal of Economics, 110, 1127-70.

4 Mankiw, Gregory N., David Romer, and David N. Weil (1992), "A Contribution to the Empirics Growth," Quarterly Journal of Economics, 107, 407-437.

5 McDonald, Scott, and Jennifer Roberts, (2002), "Growth and Multiple Forms of Human Capital in the Augmented Solow Model: A Panel Investigation,” Economic Letters, 74, 271-276. 
6 Nonneman, Walter, and Patrick Vanhoudt (1996), "A Further Augmentation of the Solow Model and the Empirics of Economic Growth for OECD Countries," Quarterly Journal of Economics, 111, 943-953.

7 OECD (2003), Beyond Rhetoric: Adult Learning Policies and Practices, OECD Publications: Paris, France.

$8 \quad$ Summers, Robert, and Alan Heston (1988), "A New Set of International Comparisons of Real Product and Price Levels Estimates for 130 Countries, 1950-85," Review of Income and Wealth, 36, 1-26.

9 Summers, Robert, Irving B. Kravis, and Alan Heston, (1980) "International Comparisons of Real

10 Product and Its Composition: 1950-77," Review of Income and Wealth, Series 26, No. 1, 19-66.

11 Summers, Robert, and Alan Heston (1991), "The Penn World Table (Mark 5): An Expanded Set of International Comparisons, 1960-1988, "' Quarterly Journal of Economics, 106, 327-368.

12 Temple, Jonathan R.W. (2000), Growth Effects of Education and Social Capital in the OECD Countries, OECD Working Paper 263. (OECD, October 12, 2000).

13 United States Census Bureau, Population Division, International Programs Center, (October 2002) .International Database.

14 World Bank Development Indicators Online (December 2002): http://www.worldbank.org/data /onlinedatabases/onlinedatabases.html

15 World Bank (December 2002), Edstats data: http://www1.worldbank.org/education/edstats/

Notes 
Table 1

Estimation of the Textbook and Augmented Solow Model

\begin{tabular}{|c|c|c|c|}
\hline \multicolumn{4}{|c|}{ Dependent variable: log GDP per working-age person in 1985} \\
\hline & & Textbook Solow Model & Augmented Solow Model \\
\hline \multicolumn{4}{|l|}{ Unrestricted Regression: } \\
\hline \multicolumn{2}{|l|}{ CONSTANT } & $\begin{array}{l}11.06 \\
(2.21)\end{array}$ & $\begin{array}{l}11.39 \\
(1.96)\end{array}$ \\
\hline \multicolumn{2}{|l|}{$\ln (\mathrm{I} / \mathrm{GDP})$} & $\begin{array}{l}0.73 \\
(0.31)\end{array}$ & $\begin{array}{l}0.60 \\
(0.28)\end{array}$ \\
\hline \multicolumn{2}{|l|}{$\ln (n+0.05)$} & $\begin{array}{l}-0.02 \\
(0.70)\end{array}$ & $\begin{array}{l}-0.33 \\
(0.63)\end{array}$ \\
\hline \multicolumn{2}{|l|}{$\ln (\mathrm{SCHOOL})$} & & $\begin{array}{c}0.57 \\
(0.22)\end{array}$ \\
\hline \multicolumn{2}{|l|}{$\operatorname{Adj} . R^{2}$} & 0.20 & 0.38 \\
\hline \multicolumn{2}{|l|}{ s.e.e. } & 0.29 & 0.26 \\
\hline \multirow[t]{2}{*}{ White test } & $\chi^{2}$ & 9.43 & 14.44 \\
\hline & $p$-value & 0.09 & 0.11 \\
\hline \multirow[t]{2}{*}{ Jarque-Bera test } & $\chi^{2}$ & 0.23 & 1.08 \\
\hline & $p$-value & 0.89 & 0.58 \\
\hline \multicolumn{4}{|l|}{ Restricted regression: } \\
\hline CONSTANT & & $\begin{array}{l}9.31 \\
(0.30)\end{array}$ & $\begin{array}{l}9.31 \\
(0.27)\end{array}$ \\
\hline $\ln (\mathrm{I} / \mathrm{GDP})-\ln (n+0.05)$ & & $\begin{array}{l}0.55 \\
(0.21)\end{array}$ & $\begin{array}{l}0.40 \\
(0.20)\end{array}$ \\
\hline \multicolumn{2}{|l|}{$\ln (\mathrm{SCHOOL})-\ln (n+0.05)$} & & $\begin{array}{l}0.55 \\
(0.22)\end{array}$ \\
\hline \multicolumn{2}{|l|}{ Adj. $R^{2}$} & 0.21 & 0.37 \\
\hline \multicolumn{2}{|l|}{ s.e.e. } & 0.29 & 0.26 \\
\hline \multirow[t]{2}{*}{ Wald test of restrictions } & $\chi^{2}$ & 0.63 & 1.16 \\
\hline & $p$-value & 0.43 & 0.28 \\
\hline \multirow[t]{2}{*}{ White test } & $\chi^{2}$ & 8.60 & 15.77 \\
\hline & $p$-value & 0.13 & 0.07 \\
\hline \multirow[t]{2}{*}{ Jarque-Bera test } & $\chi^{2}$ & 0.14 & 1.25 \\
\hline & $p$-value & 0.94 & 0.54 \\
\hline \multirow{2}{*}{\multicolumn{2}{|c|}{ Implied $\alpha$}} & 0.36 & 0.20 \\
\hline & & (0.09) & $(0.09)$ \\
\hline \multicolumn{2}{|l|}{ Implied $\beta$} & & $\begin{array}{l}0.28 \\
(0.09)\end{array}$ \\
\hline
\end{tabular}

Note: Standard errors in parentheses. 
Table 2

Estimation of the Textbook and Augmented Solow Model

Dependent variable: $\log$ GDP per working-age person in 2000

\begin{tabular}{|c|c|c|c|}
\hline \multicolumn{4}{|c|}{ Dependent variable: $\log$ GDP per working-age person in 2000} \\
\hline & & Textbook Solow Model & Augmented Solow Model \\
\hline \multicolumn{4}{|l|}{ Unrestricted Regression: } \\
\hline CONSTANT & & $\begin{array}{l}9.58 \\
(2.43)\end{array}$ & $\begin{array}{l}10.65 \\
(2.03)\end{array}$ \\
\hline $\ln (\mathrm{I} / \mathrm{GDP})$ & & $\begin{array}{c}0.62 \\
(0.38)\end{array}$ & $\begin{array}{l}0.54 \\
(0.32)\end{array}$ \\
\hline $\ln (n+0.05)$ & & $\begin{array}{l}-0.61 \\
(0.75)\end{array}$ & $\begin{array}{l}-0.88 \\
(0.62)\end{array}$ \\
\hline $\ln (\mathrm{SCHOOL})$ & & & $\begin{array}{c}0.83 \\
(0.26)\end{array}$ \\
\hline Adj. $R^{2}$ & & 0.15 & 0.42 \\
\hline s.e.e. & & 0.29 & 0.24 \\
\hline White test & $\begin{array}{l}\chi^{2} \\
p \text {-value }\end{array}$ & $\begin{array}{c}14.14 \\
0.01\end{array}$ & $\begin{array}{c}12.36 \\
0.19\end{array}$ \\
\hline Jarque-Bera test & $\begin{array}{l}\chi^{2} \\
p \text {-value }\end{array}$ & $\begin{array}{l}0.87 \\
0.65\end{array}$ & $\begin{array}{l}0.42 \\
0.82\end{array}$ \\
\hline Restricted regression: & & & \\
\hline CONSTANT & & $\begin{array}{l}9.55 \\
(0.35)\end{array}$ & $\begin{array}{l}9.45 \\
(0.29)\end{array}$ \\
\hline $\ln (\mathrm{I} / \mathrm{GDP})-\ln (n+0.05)$ & & $\begin{array}{c}0.62 \\
(0.25)\end{array}$ & $\begin{array}{c}0.41 \\
(0.22)\end{array}$ \\
\hline $\ln (\mathrm{SCHOOL})-\ln (n+0.05$ & & & $\begin{array}{l}0.81 \\
(0.26)\end{array}$ \\
\hline Adj. $R^{2}$ & & 0.19 & 0.44 \\
\hline s.e.e. & & 0.28 & 0.23 \\
\hline Wald test of restrictions & $\begin{array}{l}\chi^{2} \\
p \text {-value }\end{array}$ & $\begin{array}{l}0.00 \\
0.99\end{array}$ & $\begin{array}{l}0.36 \\
0.55\end{array}$ \\
\hline White test & $\begin{array}{l}\chi^{2} \\
p \text {-value }\end{array}$ & $\begin{array}{c}14.11 \\
0.01\end{array}$ & $\begin{array}{c}12.19 \\
0.20\end{array}$ \\
\hline Jarque-Bera test & $\begin{array}{l}\chi^{2} \\
p \text {-value }\end{array}$ & $\begin{array}{l}0.86 \\
0.67\end{array}$ & $\begin{array}{l}0.70 \\
0.71\end{array}$ \\
\hline Implied $\alpha$ & & $\begin{array}{l}0.38 \\
(0.10)\end{array}$ & $\begin{array}{l}0.18 \\
(0.09)\end{array}$ \\
\hline Implied $\beta$ & & & $\begin{array}{c}0.36 \\
(0.09) \\
\end{array}$ \\
\hline
\end{tabular}

Note: Standard errors in parentheses. 
Table 3

Tests for Unconditional and Conditional Convergence

\begin{tabular}{|c|c|c|c|c|}
\hline \multicolumn{5}{|c|}{ Dependent variable: log difference GDP per working-age person 1960-1985 } \\
\hline & & Unconditional & Textbook Solow Model & Augmented Solow Model \\
\hline \multicolumn{5}{|l|}{ Unrestricted Regression: } \\
\hline \multirow[t]{2}{*}{ CONSTANT } & & 4.17 & 4.28 & 4.96 \\
\hline & & $(0.86)$ & $(1.24)$ & $(1.20)$ \\
\hline \multirow[t]{2}{*}{$\ln (Y / L(1960))$} & & -0.37 & -0.41 & -0.46 \\
\hline & & $(0.09)$ & $(0.07)$ & $(0.06)$ \\
\hline \multirow[t]{2}{*}{$\ln (\mathrm{I} / \mathrm{GDP})$} & & & 0.48 & 0.45 \\
\hline & & & $(0.14)$ & $(0.13)$ \\
\hline \multirow{2}{*}{$\ln (n+0.05)$} & & & -0.35 & -0.44 \\
\hline & & & $(0.32)$ & $(0.30)$ \\
\hline \multirow[t]{2}{*}{$\ln (\mathrm{SCHOOL})$} & & & & 0.22 \\
\hline & & & & $(0.11)$ \\
\hline \multicolumn{2}{|l|}{$\operatorname{Adj} . R^{2}$} & 0.44 & 0.73 & 0.77 \\
\hline \multicolumn{2}{|l|}{ s.e.e. } & 0.18 & 0.13 & 0.12 \\
\hline \multirow[t]{2}{*}{ White test } & $\chi^{2}$ & 5.01 & 15.50 & 19.90 \\
\hline & $p$-value & 0.08 & 0.08 & 0.13 \\
\hline \multirow[t]{2}{*}{ Jarque-Bera test } & $\chi^{2}$ & 5.01 & 3.00 & 0.52 \\
\hline & $p$-value & 0.08 & 0.22 & 0.77 \\
\hline \multirow[t]{2}{*}{ Implied $\lambda$} & & 0.0176 & 0.0202 & 0.0236 \\
\hline & & $(0.003)$ & $(0.002)$ & $(0.003)$ \\
\hline \multicolumn{5}{|l|}{ Restricted Regression: } \\
\hline \multirow[t]{2}{*}{ CONSTANT } & & & 3.92 & 4.31 \\
\hline & & & $(0.59)$ & $(0.58)$ \\
\hline \multirow[t]{2}{*}{$\ln (Y / L(1960))$} & & & -0.41 & -0.45 \\
\hline & & & $(0.06)$ & $(0.06)$ \\
\hline \multirow[t]{2}{*}{$\ln (\mathrm{I} / \mathrm{GDP})-\ln (n+0.05)$} & & & 0.45 & 0.40 \\
\hline & & & $(0.09)$ & $(0.09)$ \\
\hline \multirow{2}{*}{\multicolumn{2}{|c|}{$\ln (\mathrm{SCHOOL})-\ln (n+0.05)$}} & & & 0.21 \\
\hline & & & & $(0.11)$ \\
\hline \multicolumn{2}{|l|}{$\operatorname{Adj} . R^{2}$} & & 0.74 & 0.77 \\
\hline \multicolumn{2}{|l|}{ s.e.e. } & & 0.12 & 0.12 \\
\hline \multirow[t]{2}{*}{ Wald test of restrictions } & $\chi^{2}$ & & 0.17 & 0.51 \\
\hline & $p$-value & & 0.68 & 0.47 \\
\hline \multirow[t]{2}{*}{ White test } & $\chi^{2}$ & & 14.83 & 19.88 \\
\hline & $p$-value & & 0.10 & 0.13 \\
\hline \multirow[t]{2}{*}{ Jarque-Bera test } & $\chi^{2}$ & & 4.14 & 1.58 \\
\hline & $p$-value & & 0.13 & 0.45 \\
\hline \multirow[t]{2}{*}{ Implied $\alpha$} & & & 0.53 & 0.38 \\
\hline & & & $(0.06)$ & $(0.08)$ \\
\hline \multirow{2}{*}{\multicolumn{2}{|c|}{ Implied $\beta$}} & & & 0.20 \\
\hline & & & & $(0.08)$ \\
\hline \multirow[t]{2}{*}{ Implied $\lambda$} & & & 0.0200 & 0.0230 \\
\hline & & & $(0.0021)$ & $(0.0026)$ \\
\hline
\end{tabular}

Note: Standard errors in parentheses. 
Table 4

Tests for Unconditional and Conditional Convergence

\begin{tabular}{|c|c|c|c|c|}
\hline \multicolumn{5}{|c|}{ Dependent variable: log difference GDP per working-age person 1960-2000 } \\
\hline & & Unconditional & Textbook Solow Model & Augmented Solow Model \\
\hline \multicolumn{5}{|l|}{ Unrestricted Regression: } \\
\hline \multirow[t]{2}{*}{ CONSTANT } & & 5.49 & 3.93 & 5.59 \\
\hline & & $(1.03)$ & $(1.90)$ & $(1.72)$ \\
\hline \multirow[t]{2}{*}{$\ln (Y / L(1960))$} & & -0.48 & -0.50 & -0.58 \\
\hline & & $(0.11)$ & $(0.09)$ & $(0.08)$ \\
\hline \multirow[t]{2}{*}{$\ln (\mathrm{I} / \mathrm{GDP})$} & & & 0.40 & 0.39 \\
\hline & & & $(0.25)$ & $(0.21)$ \\
\hline \multirow[t]{2}{*}{$\ln (n+0.05)$} & & & -0.84 & -0.94 \\
\hline & & & $(0.50)$ & $(0.42)$ \\
\hline \multicolumn{2}{|l|}{$\ln (\mathrm{SCHOOL})$} & & & $\begin{array}{c}0.52 \\
(0.19)\end{array}$ \\
\hline \multicolumn{2}{|l|}{$\operatorname{Adj} . R^{2}$} & 0.47 & 0.63 & 0.74 \\
\hline \multicolumn{2}{|l|}{ s.e.e. } & 0.22 & 0.18 & 0.16 \\
\hline \multirow[t]{2}{*}{ White test } & $\chi^{2}$ & 6.48 & 15.35 & 17.96 \\
\hline & $p$-value & 0.04 & 0.08 & 0.21 \\
\hline \multirow[t]{2}{*}{ Jarque-Bera test } & $\chi^{2}$ & 10.44 & 1.79 & 0.04 \\
\hline & $p$-value & 0.01 & 0.41 & 0.98 \\
\hline Implied $\lambda$ & & 0.0159 & 0.0167 & 0.0209 \\
\hline \multicolumn{4}{|l|}{ Restricted Regression: } & $(0.004)$ \\
\hline CONSTANT & & & $\begin{array}{c}5.07 \\
(0.86)\end{array}$ & $\begin{array}{c}5.67 \\
(0.74)\end{array}$ \\
\hline $\ln (Y / L(1960))$ & & & $\begin{array}{l}-0.51 \\
(0.09)\end{array}$ & $\begin{array}{l}-0.58 \\
(0.08)\end{array}$ \\
\hline $\ln (\mathrm{I} / \mathrm{GDP})-\ln (n+0.05)$ & & & $\begin{array}{l}0.52 \\
(0.17)\end{array}$ & $\begin{array}{c}0.40 \\
(0.14)\end{array}$ \\
\hline \multicolumn{2}{|l|}{$\ln (\mathrm{SCHOOL})-\ln (n+0.05)$} & & & $\begin{array}{c}0.52 \\
(0.17)\end{array}$ \\
\hline \multicolumn{2}{|l|}{$\operatorname{Adj} . R^{2}$} & & 0.64 & 0.75 \\
\hline \multicolumn{2}{|l|}{ s.e.e. } & & 0.18 & 0.15 \\
\hline \multirow[t]{2}{*}{ Wald test of restrictions } & $\chi^{2}$ & & 0.40 & 0.0001 \\
\hline & $p$-value & & 0.53 & 0.99 \\
\hline \multirow[t]{2}{*}{ White test } & $\chi^{2}$ & & 16.01 & 17.78 \\
\hline & $p$-value & & 0.07 & 0.22 \\
\hline \multirow[t]{2}{*}{ Jarque-Bera test } & $\chi^{2}$ & & 1.86 & 0.04 \\
\hline & $p$-value & & 0.39 & 0.98 \\
\hline Implied $\alpha$ & & & $\begin{array}{l}0.50 \\
(0.09)\end{array}$ & $\begin{array}{l}0.27 \\
(0.09)\end{array}$ \\
\hline \multicolumn{2}{|l|}{ Implied $\beta$} & & & $\begin{array}{l}0.35 \\
(0.09)\end{array}$ \\
\hline Implied $\lambda$ & & & $\begin{array}{c}0.0174 \\
(0.0032)\end{array}$ & $\begin{array}{c}0.0209 \\
(0.0039)\end{array}$ \\
\hline
\end{tabular}

Note: Standard errors in parentheses. 


\section{Endnotes}

1 Mankiw, Romer And Weil (1992) estimated the augmented Solow model using three samples: 1) a sample of 98 "non oil" countries; 2) a sample of 75 countries in the "intermediate and industrialized level" of development; and 3) a sample of 22 OECD countries.

2 Mankiw, Romer, and Weil (1992) used the Mark 4.0 version of the Penn World Table (Summers and Heston, 1988). Nonneman and Vanhoudt (1996) used the Mark 5.0 version of the Penn World Table (Summers and Heston, 1991).

3 A detailed listing of all changes between the previous versions and version 6.1 of the Penn World Table is available in the "What's New" section of the website at: http://pwt.econ.upenn.edu/.

4 The purpose of their project is to provide a set of real national accounts and each successive version is a movement towards that outcome (Summers and Heston, 1991, p. 327). A history of the project, the evolution of the different versions, details on how the series were constructed, and comparisons between the versions 4.0 and 5.0 of the Penn World Table can be found in Summers and Heston (1991).

${ }^{5}$ Prior to estimation, we examined the correlations between $\ln (\mathrm{I} / \mathrm{GDP}), \ln (\mathrm{n}+0.05)$ and $\ln (\mathrm{SCHOOL})$. The values of the correlation coefficients did not suggest any serious problem with multicollinearity. For the sample period 19601985, the largest correlation coefficient, -0.462 , was between $\ln (\mathrm{I} / \mathrm{GDP})$ and $\ln (n+0.05)$. The correlation coefficients for the sample period 1960-2000 were similar to those found over the sample period 1960-1985 with the largest correlation coefficient, -0.458 , also between $\ln (\mathrm{I} / \mathrm{GDP})$ and $\ln (n+0.05)$.

6 This approach has been subjected to a variety of criticisms. One of the main criticisms was raised first by Islam (1995), who argued that the country-specific aspects of the aggregate production function, which are correlated with the explanatory variables, are ignored in the single cross-section approach used by Mankiw, Romer and Weil (1992), thus imparting an omitted variable bias to their estimates. McDonald and Roberts (2002), however, reported that country-specific effects are marginal for the OECD sample.

${ }^{7}$ Mankiw, Romer and Weil (1992) do not report the mean and standard deviation of the net marginal product of physical capital for the OECD countries; however, their data, together with their estimate of $\alpha$ produce a mean of 0.4 per cent and a standard deviation of 0.8 per cent for the steady state net marginal product of physical capital for the OECD countries.

${ }^{8}$ We also briefly revisited Nonneman and Vanhoudt's (1996) analysis. As noted in the introduction, Nonneman and Vanhoudt (1996) have argued that the poor performance of the augmented Solow model is due to the omission of the third type of capital, technological know-how. To further assess that version 6.1 of the Penn World Table makes a difference in the performance of the augmented Solow model, we re-estimated their extended version of the Solow model using the Penn World Table 6.1 in conjunction with their data on technological know-how for the sample period 1960-1985. At first glance, their version of the extended Solow model seemed promising as the adjusted $R^{2}$ increases from 0.73 to 0.77 when the Penn World Table 6.1 are used. However, several problems arose that made their formulation even more untenable. First, the results provide even less support for the predictions of the Solow model as well as for several of the Mankiw, Romer and Weil (1992) conclusions, as investment in human capital and population growth remained unimportant in our estimated extended Solow model. Second, the linear restrictions implied by their extension are rejected at the conventional 0.05 level by the Wald test $\chi^{2}=5.17$, p-value $=0.016)$. This additional statistical evidence makes the Solow model as extended by Nonneman and Vanhoudt (1996) irrelevant in accounting for the variation in the steady-state level of income for the OECD countries, despite the increase in the reported explanatory power. 